\title{
Results of Physiotherapeutic Postural screening in Children and Young people in Montenegro
}

\author{
Krsto Kovacevic* \\ Master of Physical Therapy, President of the Chamber of Physiotherapists of Montenegro, Balkans \\ *Corresponding author: Krsto Kovacevic, Master of Physical Therapy, President of the Chamber of Physiotherapists of Montenegro, \\ Balkans
}

\begin{tabular}{ll}
\hline ARTICLE INFO ABSTRACT \\
\hline
\end{tabular}

Received: 姫 July 17, 2019

Published: 慧 July 24, 2019

Citation: Krsto Kovacevic. Results of Physiotherapeutic Postural screening in Children and Young people in Montenegro. Biomed J Sci \& Tech Res 20(1)-2019. BJSTR. MS.ID.003383.
Keywords: Postural screening; Physiotherapists

Abbreviations: N: Number; X: Arithmetic Mean; SD: Standard Deviation

\section{Introduction}

The research was carried out within the campaign "Straighten up and practice!", designed as a free counseling service in public places in several Montenegrin cities, and intended to recognize and identify postural problems in children and young people in time in Montenegro. The work included 1,181 respondents, out of which $562(47.6 \%)$ boys and 619 (52.4\%) girls. The tests were conducted in 17 cities of Montenegro (Podgorica, Bijelo Polje, Cetinje, Bar, Niksic, Ulcinj, Budva, Berane, Herceg Novi, Kolasin, Rozaje, Zabljak, Petnjica, Danilovgrad, Pljevlja, Kotor and Tivat) from 15.03.2015. until 27.09.2015. Checks for the purpose of detecting postural problems were carried out by physiotherapists (specialists of applied physiotherapy) at several points for them. Respondents came voluntarily with their parents at the invitation sent through the Ministry of Education of Montenegro, the Association "Parents" and the Directorate for Youth and Sport of Montenegro [1-10].

\section{Materials and Methods}

Respondents are children and young people between the ages of 5 and 25. The screening method records postural status data. The work included 1181 subjects, out of which 562 boys and 619 girls. Tests were conducted in 17 cities of Montenegro (Podgorica, Bijelo Polje, Cetinje, Bar, Niksic, Ulcinj, Budva, Berane, Herceg Novi, Kolasin, Rozaje, Zabljak, Petnjica, Danilovgrad, Pljevlja, Kotor and Tivat) [11-20]. Checks for the purpose of detecting postural problems were carried out by physiotherapists (specialists of applied physiotherapy) at several points for them. Respondents came voluntarily with their parents at the invitation sent through the Ministry of Education of Montenegro, the Association "Parents" and the Directorate for Youth and Sport of Montenegro. The research lasted from 15.03.2015. to 15.10.2015. The basic demographics were collected from the respondents. We used generally accepted methods of observation and measurement to determine postural problems. We observe head position, shoulder position, bladder position, Lorenc's triangular size, folded elbow positions, pelvis inclination, Iliopsoas muscle flexibility, knee position, foot position and Adams test (preclined). We measured: body height, body weight and leg length. Evaluation sheets that were numbered and made on a scrapped paper were filled based on the examination so that one copy (original) of this list was given to parents. The data collected were analyzed using the descriptive statistics method. Statistical analyzes were performed by IBM SPSS Statistics 23. The categorical variables are represented by the number (n) and percentage (\%) of the observations, and the continuous variable by the arithmetic mean (x) and the standard deviation (SD) or the median with quartile ranges, depending on the normality of the data distribution.

Distribution regularity was evaluated based on frequency histogram and calculated using the Shapiro-Wilk test. For the 
analysis of the categorical screening variables, the variable age was transformed and recoded into categories with approximately the same distribution of the number of respondents by category. Screening results were analyzed using descriptive statistics; a hisquare $\left(x^{2}\right)$ test was used to compare the groups. The difference between the groups was considered significant if $p<0.05$ [21-29].

\section{Results}

The results of the study showed that: in $25.5 \%$ of respondents, the head is in the protege; in $29.5 \%$ of subjects with lower right shoulder; in $24.7 \%$ of the subjects lowered left shoulder; in $41.6 \%$ of shoulders in the protege; in $36.2 \%$ of respondents there is a winginess of both blades; in $54.9 \%$ of subjects, the asymmetric position of the lower angle of the blades is present; in $70.5 \%$ of respondents, the asymmetric position of Lorenz's triangles is present; in $18.8 \%$ of subjects, the front pelvis is present; in $1.1 \%$ of the respondents the asymmetry of the SIAS position is present; in $52.6 \%$ of respondents there is a contract of both M. Iliopsoas; in $13.2 \%$ of respondents, one of the knee deformities is present; in $72.7 \%$ of the subjects there are lowered vaults of both feet; in $22.0 \%$ of subjects, valgus is present in both Achilles tendons; in $3.1 \%$ of subjects, there is a bilateral halux valgus; $1.6 \%$ of respondents had a leg difference of $1 \mathrm{~cm}$; Of the total of 206 respondents (17.4\%) who have registered gestures, the same is corrected in 122 respondents (59.22\%), ie it is not corrected at 84 (40.78\%). In $82.6 \%$ of subjects, no hump was recorded.

\section{Conclusion}

The results of this research can be used to point out the application of certain activities so that postural deformities can be detected, controlled, prevented and treated efficiently by effective programs of preventive and therapeutic exercises created and applied by physiotherapists. This certainly includes the introduction of several systematic reviews, prescribing the therapies necessary to prevent the development of postural deformities, during the school year during which, in co-operation with other professionals, special attention will be paid to the timely identification of postural deformities among students. In Montenegrin society, the presence of postural deformities is understood too lightly because parents are not sufficiently familiar with these conditions and their consequences. On the basis of the obtained results, certain recommendations were made to parents and the competent state authorities for adequate action in order to prevent and treat postural deformities in children in primary schools.

\section{References}

1. Standring S (2005) Gray's Anatomy-The Anatomical Basis of Clinical Practice. Elsevier Churchill Livingstone.

2. Mc Evoy MP, Grimmer K (2005) Reliability of upright posture measurements in primary school children. BMC Musculoscelet Disord 29: 6-35.
3. Adar BZ (2004) Risk Factors of Prolonged Sitting and Lack of Physical Activity in Relate to Postural Deformities, Muscles Tension and Backache Among Israeli Children. A clinical cross-sectional research. Doctoral Thesis, Semmelweis University Budapest.

4. Savić K Demeši Č (2006) Loše držanje tela i deformiteti kičmenog stuba $\mathrm{u}$ razvojnom dobu. U: Edukativni seminar-Ortopedski problemi $\mathrm{u}$ pedijatriji. Medicinski fakultet. Novi Sad p. 18-25.

5. Lafond D, Descarreaux M, Normand MC, Harrison DE (2007) Postural development in school children: a cross-sectional study. Chiropra Osteopat 4: 15-21.

6. Donathné Forgács B (2005) Gerincbetegségek gyógytestnevelése iskoláskorban. Magánkiadás.

7. Penha PJ, Joao SM, Casarotto RA, Amino CJ, Penteado DC (2005) Postural assessment of girls between 7 and 10 years of age. Clinics 60(1).

8. Gandreault N, Ansenault B, Laviere C, DeSerres SJ, Rivard CH, et al. (2005) Assessement of the paraspinal muscles of subjects presenting idiopathic scoliosis. BMC Musculosceletal Disorders 6: 14

9. Wong HK, Hui JH, Rajan U, Chia HP (2005) Idiopathic scoliosis in Singapore schoolchildren: a prevalence study 15 years into the screening program. Spine 30(10): 1188-1196.

10. Yilkoski M (2005) Growth and progression of adolescent idiopathic scoliosis in girls. J Pediatr Orthoped B 14(5): 320-324.

11. Kawakami N, Tsuji T, Imagama S, Lenke L, Puno R, et al. (2009) Classification of congenital scoliosis and kyphosis-A new approach to the threedimensional classification for progressive vertebral anomalies requiring operativ treatment. Spine 34(17): 1756-1765.

12. Harris EJ, Vanore JV, Thomas JL, Kravitz SR, Mendelson SA, et al. (2004) Diagnosis and treatment of pediatric flatfoot. J Foot Ankle Surg 43(6): 341-373.

13. Mihajlović I, Tončev I, Hmjelovjec I (2008) Prevalance of flatfoot deformity in boys depending on their age. Acta Kinesiologica 2: 103106.

14. Vukašinović Z, Živković Z, Vučetić Č (2009) Ravna stopala kod dece. Srp Arh Celok Lek 137(5-6): 320-322.

15. Rose CRE (2007) Flat feet in Children: When should they be treated? The Internet Journal of Orthopedic Surgery 6(1).

16. Mosca VS (1995) Flexibile flatfoot and skewfoot. J Bone Joint Surg 77(12): 1937-1945.

17. Staheli LT (1999) Planovalgus foot deformity. Current status. I Am Podiatr Med Assoc 89(2): 94-99.

18. Goldberg CJ, Moore DP, Fogarty EE, Dowling FE (2008) Scoliosis: a review. Pediatric Surg Int 24(2): 129-144.

19. Grivas TB, WadeMH, Negrini S, Joseph PO Brien, Toru Maruyama, et al. (2007) SOSORT consensus paper: school screening for scoliosis: Where are we today? Scoliosis 2(1): 17.

20. Aharon S Finestone, Marcus G, Anekstein Y, Mirovsky Y, Agar G (2013) Assessing kyphosis with SpineScan: another attempt to reduce our dependence on radiography. Spine J 13(8): 926-931.

21. Wickens I Kiputh (1937) Stefanović i suradnici (1972) Tribastone (1994) Palmer i Epler (1998) Watson i Mac Donncha (2000) Straker Mekhora (2000) Paušić (2005) McEvoy i Grimmer (2005).

22. Conić S (2014) Klinička kineziterapija u internoj medicini i pedijatriji. Visoka sportska i zdravstvena škola Beograd 15.

23. Côté P, Kreitz BG, Cassidy JD, Dzus AK, Martel J (1998)A study of the diagnostic accuracy and reliability of the Scoliometer and Adam's forward bend test. Spine (Phila Pa 1976) 23(7): 796-802. 
24. Jovović V, Radomir Čanjak (2014) Komparativna analiza sagitalnih poremećaja kičmenog stuba mlađih adolescentkinja ruralne i urbane sredine. Proceedings 5: 1986-8146.

25. Bajrić 0, Sanja Lolic, Ratko Peric, Drazen Kovacevic (2012) Učestalost deformiteta kičmenog stuba kod učenika starijih razreda osnovne škole. Sportske nauke i zdravlje 2(2): 175-181.

26. Mihajlović I, Smajić Miroslav, Sente Jelena (2010) Učestalost deformiteta stopala kod devojčica predškolskog uzrasta. Vojnosanit Pregl 67(11): 928-932.

\section{ISSN: 2574-1241}

DOI: 10.26717/BJSTR.2019.20.003383

Krsto Kovacevic. Biomed J Sci \& Tech Res

(c) (P) This work is licensed under Creative

Submission Link: https://biomedres.us/submit-manuscript.php
27. Puzović V, Puzović Vladimirb, Đorđević Dušicab, Obrenović Milošc, Medić Veselinc, et al. (2012) Prevalenca deformiteta kičme kod dece uzrasta 7 - 11 godina. Med Čas 46(4): 187-190.

28. Gojković D (2018) Učestalost deformiteta skolioze i ravnih stopala kod učenika iii,v.vii razreda osnovne škole. Crnogorska spo-rtska akademija. Sport Mont. časopis br. 37,38,39: 67-73.

29. Jehle C, Jürgen Kühnis (2011) Postural assessment of primary school children in Liechtenstein: a longitudinal study 2008-2010. Sportmedizin und Sporttraumatologie 59(3): 133-135.

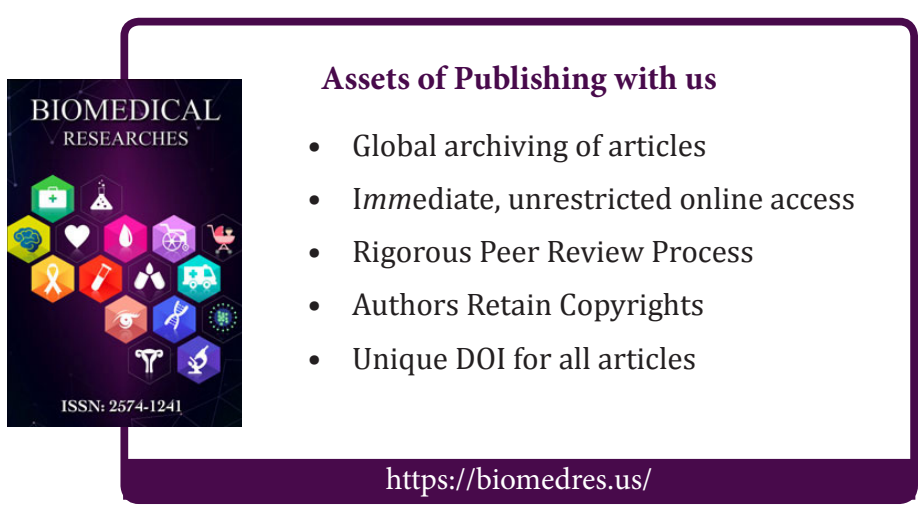

